\title{
EFEKTYWNOŚĆ TECHNICZNA SPÓŁEK AGENCJI NIERUCHOMOŚCI ROLNYCH W LATACH 1994-2012
}

\author{
Mirostaw Helta
}

Agencja Nieruchomości Rolnych

\begin{abstract}
Słowa kluczowe: efektywność techniczna, metoda DEA, Agencja Nieruchomości Rolnych (ANR) Key words: technical efficiency, DEA method, Agricultural Property Agency (APA)

S y n o p s i s. Celem pracy jest określenie efektywności technicznej spółek należących do Agencji Nieruchomości Rolnych (ANR) w latach 1994-2012. W Polsce spółki te pełnią znaczną rolę w hodowli roślin i zwierząt. W badaniach zastosowano nieparametryczną metodę DEA. Z badań wynika, że w badanym okresie spółki ANR zwiększyły efektywność techniczną. Najwyższą efektywnością techniczną CCR, BCC oraz efektywnością skali charakteryzowały się spółki hodowli roślin i spółki hodowli zwierząt. Najniższe wskaźniki efektywności technicznej odnotowano w spółkach prowadzących hodowlę koni.
\end{abstract}

\section{WSTĘP}

Głównym celem spółek strategicznych Agencji Nieruchomości Rolnych (ANR) jest kreowanie postępu biologicznego. Zadaniem badanych spółek hodowli roślin (HR) jest prowadzenie hodowli twórczej i zachowawczej roślin rolniczych oraz ogrodniczych. Grupa spółek hodowli zwierząt (HZ) zajmuje się hodowlą bydła, trzody chlewnej i owiec. Podstawowym celem pracy hodowlanej w tej grupie jest produkcja materiału zarodowego dla doskonalenia populacji masowej zwierząt gospodarskich. Zasadniczym celem spółek tworzących grupę stadnin koni jest doskonalenie krajowej populacji ras koni. Należy podkreślić, że oprócz działalności hodowlanej badane podmioty zajmują się także produkcją surowców roślinnych i zwierzęcych.

Spółki ANR mają dominującą pozycję w hodowli roślin w Polsce [Helta, Oprządek 2012]. Są one właścicielami 52\% odmian roślin rolniczych i $60 \%$ odmian roślin warzywnych pochodzących z krajowej hodowli wpisanych do rejestru odmian. Natomiast udział odmian spółek ANR we wszystkich odmianach wpisanych do rejestru odmian wynosi 33\% (rośliny rolnicze 26\% i warzywne 44\%). Znaczenie spółek ANR w realizacji krajowych programów genetycznego doskonalenia zwierząt ze względu na wysoki potencjał genetyczny utrzymywanych zwierząt jest bardzo duże, szczególnie w hodowli bydła mlecznego. W spółkach prowadzących hodowlę bydła mlecznego znajduje się $64 \%$ ogółu matek buhajów znajdujących się w populacji krajowej. Na potrzeby programu genetycznego doskonalenia bydła mlecznego dostarczany jest męski materiał hodowlany, a na potrzeby hodowli terenowej wysokiej jakości jałówki cielne. 
Celem badań było określenie efektywności technicznej strategicznych spółek ANR w latach 1994-2012 przy zastosowaniu nieparametrycznej metody Data Envelopment Analysis (DEA).

\section{METODY BADAŃ}

Metody badania efektywności można podzielić na trzy grupy. Do pierwszej grupy zalicza się metody wskaźnikowe. Wskaźniki są odpowiednie przy badaniu efektywności jednego czynnika i sprowadzają się zazwyczaj do prostych wskaźników typu zysk na hektar lub dochód na zatrudnionego czy różnych wskaźników wykorzystywanych we wskaźnikowej analizie finansowej. Do drugiej grupy należą metody parametryczne. Metodami tymi bada się efektywność za pomocą ilościowych modeli ekonomicznych (stochastycznych i niestochastycznych). Trzecia grupa metod to metody nieparametryczne. Należą do nich zastosowana w badaniach metoda DEA, która nie wymaga ustalania związków między efektami i nakładami i pozwala na badanie obiektów z kilkoma efektami i kilkoma nakładami jednocześnie oraz nakłady i efekty w badaniu mogą być wyrażane w różnych jednostkach.

Pomiar efektywności technicznej wykonano metodą analizy granicznej (DEA). Zastosowano dwa alternatywne modele: model CCR zakładający stałe efekty skali (ang. CRS) [Charnes i in. 1978] i model BCC zakładający zmienne efekty skali (ang. VRS) [Banker i in. 1984], co umożliwiło również obliczenie efektywności skali (ang. SE) dla badanych gospodarstw. Modele CCR i BCC wykorzystują jedną z najbardziej popularnych technik zaproponowanych w pracy Production Frontiers [Färe i in. 1995]. Do obliczenia efektywności technicznej wykorzystuje się koncepcję pomiaru efektywności przedstawioną przez Tima Coelliego, Prasada Rao i Georga Battese [Coelli i in. 1998]. Koncepcja ta zakłada, że na całkowitą efektywność ekonomiczną wpływają dwa składniki: efektywność techniczna i alokacyjna. W zastosowanej metodzie efektywność techniczna definiowana jest jako relacja rzeczywistej produktywności do możliwie najwyższej produktywności. Na podstawie danych można oszacować krzywą efektywności, którą wyznaczają obiekty efektywne. Poza tą krzywą znajdują się obiekty wykazujące się pewnym stopniem nieefektywności i dzięki tej krzywej można ten stopień obliczyć. Ogólnym założeniem tej metody jest to, że efektywność danego czynnika produkcji jest ilorazem efektu do nakładu, a rozwijając to do sytuacji wielowymiarowej- można przyjąć, że dysponując $s$-efektami i $m$-nakładami efektywność przyjmuje postać:

$$
\frac{\sum_{r=1}^{s} u_{r} y_{r}}{\sum_{i=1}^{m} v_{i} x_{i}}=\frac{u_{1} y_{1}+u_{2} y_{2}+\ldots \ldots+u_{s} y_{s}}{v_{1} x_{1}+v_{2} x_{2}+\ldots \ldots .+v_{m} x_{m}},
$$

gdzie: $y_{\mathrm{r}}$ - wartość efektu, $u_{\mathrm{r}}$ - waga efektu, $x_{\mathrm{i}}$ - wartość nakładu, $v_{\mathrm{i}}-$ waga nakładu.

Sprowadzenie nakładów i efektów do wielkości syntetycznych daje możliwość kalkulacji współczynnika efektywności technicznej. Dla każdego obiektu rozwiązuje się zadanie programowania liniowego, gdzie obliczany współczynnik efektywności ma postać funkcji celu poddanej maksymalizacji, a zmiennymi optymalizowanymi są wagi efektów i wagi nakładów [Charnes i in. 1978]. Pisali o tym także Grzegorz Rogowski [Rogowski 1998] i Bogusław Guzik [Guzik 2009]. 
Zastosowanie analizy CRS jest odpowiednie tylko wtedy, gdy wszystkie firmy funkcjonują w podobnych warunkach, a osiągana skala ich dochodu jest optymalna. Zmienne warunki gospodarowania, np.: konkurencja, ograniczenia finansowe czy technologiczne itp., mogą spowodować, że firma nie będzie funkcjonowała w optymalnym układzie. Rajiv Banker, Abraham Charnes i William Cooper w 1984 roku zaproponowali rozszerzenie modelu DEA, przy założeniu CRS, uwzględniające VRS [Coelli i in. 1988]. Zastosowanie takiego rodzaju modeli pozwala uniknąć wpływu braku optymalnych warunków funkcjonowania firm na skalę efektywności (SE). Otrzymane metodą DEA VRS współczynniki efektywności są bardziej precyzyjne niż wyniki uzyskane przy założeniu CRS. Metoda ta zakłada, że obiekt uznawany za nieefektywny jest nim tylko w odniesieniu do obiektów o podobnej wielkości.

Technika analizy VRS wymaga uzyskania skali efektywności dla każdego obiektu firmy. Skalę taką można otrzymać, realizując obie techniki (CRS i VRS). Wówczas miara efektywności technicznej uzyskana w analizie CRS rozkłada się na dwa czynniki: skalę efektywności (SE) i tzw. czystą efektywność techniczną (PTE). Jeżeli pojawia się różnica pomiędzy wynikami efektywności technicznej poszczególnych analiz CRS i VRS, świadczy to o tym, że dana firma ma nieefektywną skalę.

Do obliczeń przyjęto model gospodarstwa w postaci:

- efekt: - przychody ze sprzedaży wraz z dotacjami i dopłatami bezpośrednimi,

- nakłady: - powierzchnia użytków rolnych (ha),

- wartość majątku trwałego (tys. zł),

- koszt płac wraz z pochodnymi płac (tys. zł),

- koszt zużycia materiałów i energii (tys. zł).

Analizowany model był ukierunkowany na minimalizację nakładów. Należy podkreślić, że w zastosowaniach DEA w rolnictwie podejście takie jest najbardziej uprawnione, ponieważ decydenci mają realny wpływ na wielkość zastosowanych nakładów. Dodatkowo w rolnictwie duży wpływ na efektywność mają terminy stosowania nakładów plonotwórczych.

Zmienne dobrano pod względem merytorycznym zgodnie z celem pracy. W praktyce pomiar efektywności sprowadza się zazwyczaj do pomiarów cząstkowych efektywności podstawowych zasobów i czynników produkcji. Do czynników tych zaliczamy ziemię, kapitał i pracę. Nakłady ziemi wyrażono w powierzchni użytków rolnych, kapitał wyrażono za pomocą dwóch zmiennych, tj. wartości majątku trwałego i kosztu zużycia materiałów i energii. Natomiast nakłady pracy ujęto jako jej koszt wraz ze świadczeniami na rzecz pracowników. Należy zauważyć, że w okresie tworzenia badanych spółek decyzje o ich areale i wyposażeniu w środki trwałe podejmowano w ANR, natomiast decyzje o zatrudnieniu (funduszu płac), kosztach zużycia materiałów i energii należały do władz spółek. Efektem w modelu była wartość przychodów wraz z dotacjami i dopłatami bezpośrednimi, ponieważ wysokość dotacji i dopłat wpływa m.in. na poprawę zdolności kredytowej, poprawiają one płynność finansową gospodarstw, wpływają na stosowanie postępu naukowo-technicznego [Góral 2015].

Przy doborze zmiennych kierowano się również doświadczeniami badaczy zagranicznych i krajowych, szczególnie w odniesieniu do badań związanych z rolnictwem [Battese, Coelli 1992, Thiele, Brodersen 1997, Czasch i in. 1999, Świtłyk 2001, Rusielik 2000, Ziółkowska 2008, Kulawik 2008]. Należy podkreślić, że w polskiej literaturze ekonomiczno-rolniczej brakuje opracowań dotyczących racjonalności gospodarowania $\mathrm{w}$ spółkach ANR (za wyjątkiem [Rusielik 2000]). Znakomita większość opracowań badaczy zarówno polskich, jak i zagranicznych dotyczących efektywności technicznej oparta 
jest na danych starego systemu rachunkowości rolnej lub danych FADN i dotyczą one gospodarstw rodzinnych lub gospodarstw powstałych na bazie Zasobu Własności Rolnej Skarbu Państwa (ZWRSP).

Metoda DEA w polskiej literaturze ekonomiczno-rolniczej jest często wykorzystywana. Stosowana była m.in. do określania efektywności technicznej produkcji mleka [Rusielik, Świtłyk 2012, Marzec, Pisulewski 2013, Marzec i in. 2015], efektywności skali produkcji trzody chlewnej [Szymańska 2011], efektywności przedsiębiorstw przemysłu zbożowo-młynarskiego [Jarzębowski 2015], pomiaru efektywności skali produkcji przedsiębiorstw przetwórstwa mleka [Baran 2010] oraz efektywności technicznej rolnictwa w skali kraju [Świtłyk 2011].

Dane do badań uzyskano metodą dokumentacyjną, korzystając z opublikowanych sprawozdań finansowych (bilansów i rachunków zysków i strat) oraz sprawozdań zarządów badanych spółek. Analizie poddano cztery grupy obiektów. Pierwszą tworzyła zbiorowość generalna badanych spółek, drugą grupą były spółki hodowli roślin rolniczych i hodowli roślin ogrodniczych, do trzeciej grupy zaliczono spółki hodowli zarodowej zwierząt, a do czwartej przypisano stadniny koni. Ze względu na ich specyfikę z obliczeń wyłączono stada ogierów.

W opisie wyników badań spółki podzielono na trzy grupy: efektywne, w których współczynnik efektywności technicznej wynosił 100\%, zbliżone do efektywnych (współczynnik efektywności technicznej mieścił się w granicach 90,0-99,99\%) i nieefektywne (współczynnik efektywności technicznej wynosił mniej niż 90\%). Założono, że w spółkach efektywnych nie występuje potrzeba ingerencji w zarządzanie spółkami, spółki zaliczone do grupy zbliżonych do efektywnych wymagają niewielkich korekt w zarządzaniu, a spółki zaliczane do nieefektywnych wymagają podjęcia wielu działań w celu poprawy zarządzania nimi.

\section{WYNIKI BADAŃ}

Na rysunkach 1.-4. i w tabelach 1.-3. przedstawiono wyniki obliczeń współczynników efektywności technicznej BCC badanych przedsiębiorstw, które wykonano dla modelu zorientowanego na minimalizację nakładów oraz podstawowe statystyki opisowe. Do obliczeń przyjęto zbiorowość generalną badanych spółek, mimo że kilka spółek w niektórych latach (2007-2010) charakteryzowało się silniejszą asymetrią, która wynikała z tego, iż spółki te przygotowywane były do prywatyzacji i częściowo likwidowano w nich produkcję.

Tendencją malejącą (tab. 1.) charakteryzowały się odchylenie standardowe i współczynniki zmienności. W modelu CCR w 1994 roku wielkość odchylenia standardowego wynosiła 19,3, natomiast w 2012 roku jego wielkość ukształtowała się na poziomie 13,3. Współczynniki zmienności dla tego modelu wynosiły odpowiednio 33,4 i 16,2\%. W modelu BCC wysokość odchylenia standardowego wynosiła odpowiednio 18,7 i 8,6, a wielkość współczynnika zmienności 27,8 i 9,4\%. Obliczone dla efektywności skali omawiane wielkości wynosiły odpowiednio dla odchylenia standardowego 16,5 i 11,9, a dla współczynnika zmienności 19,0 i 13,2\%.

W modelu CCR (tab. 2.) w grupie spółek efektywnych i w grupie zbliżonych do efektywnych w 1994 roku znajdowało się 8 obiektów, a w 2012 roku - 13. W modelu BCC takich obiektów było odpowiednio 14 i 27, a określając efektywność skali takich obiektów było 52 i 31 . 


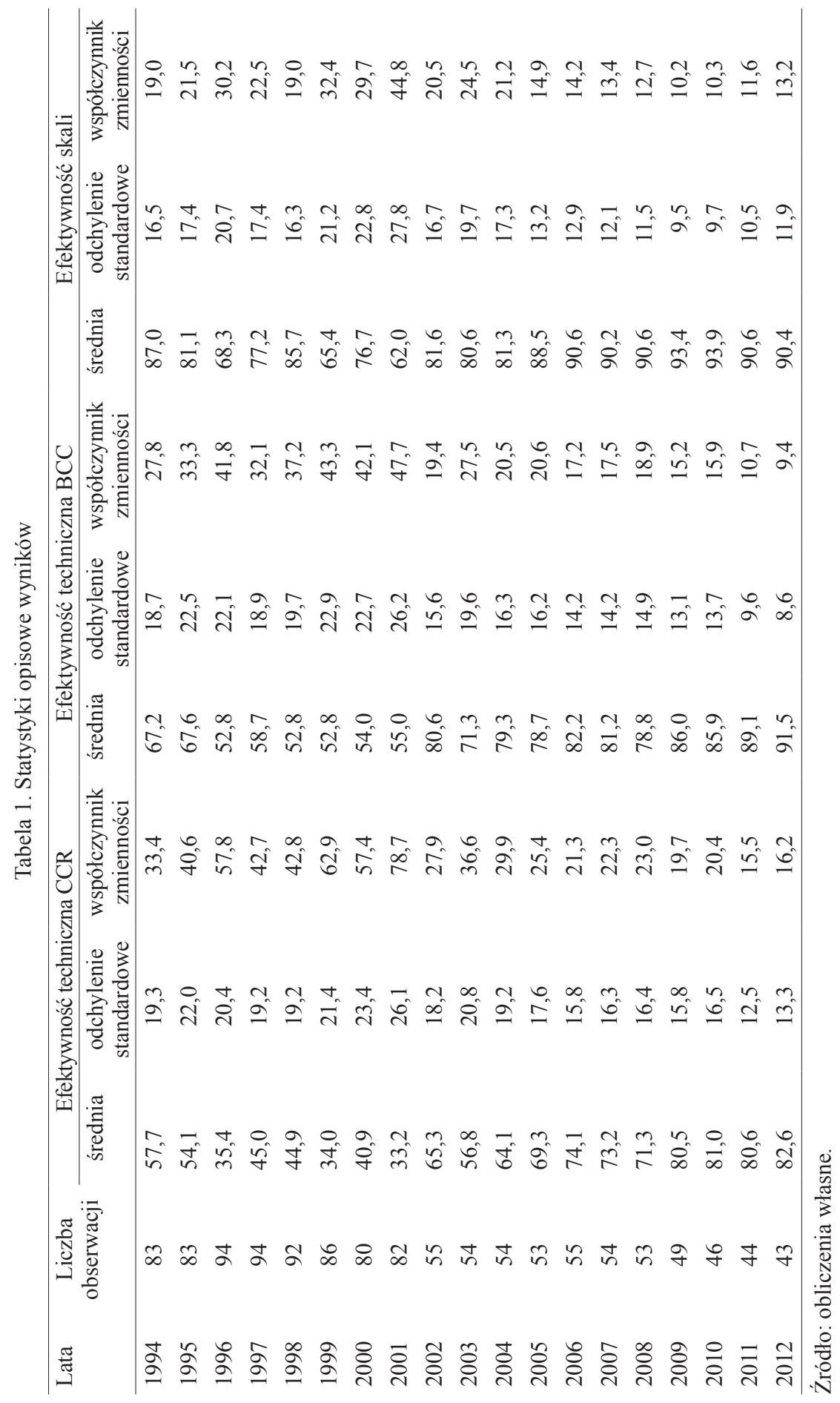




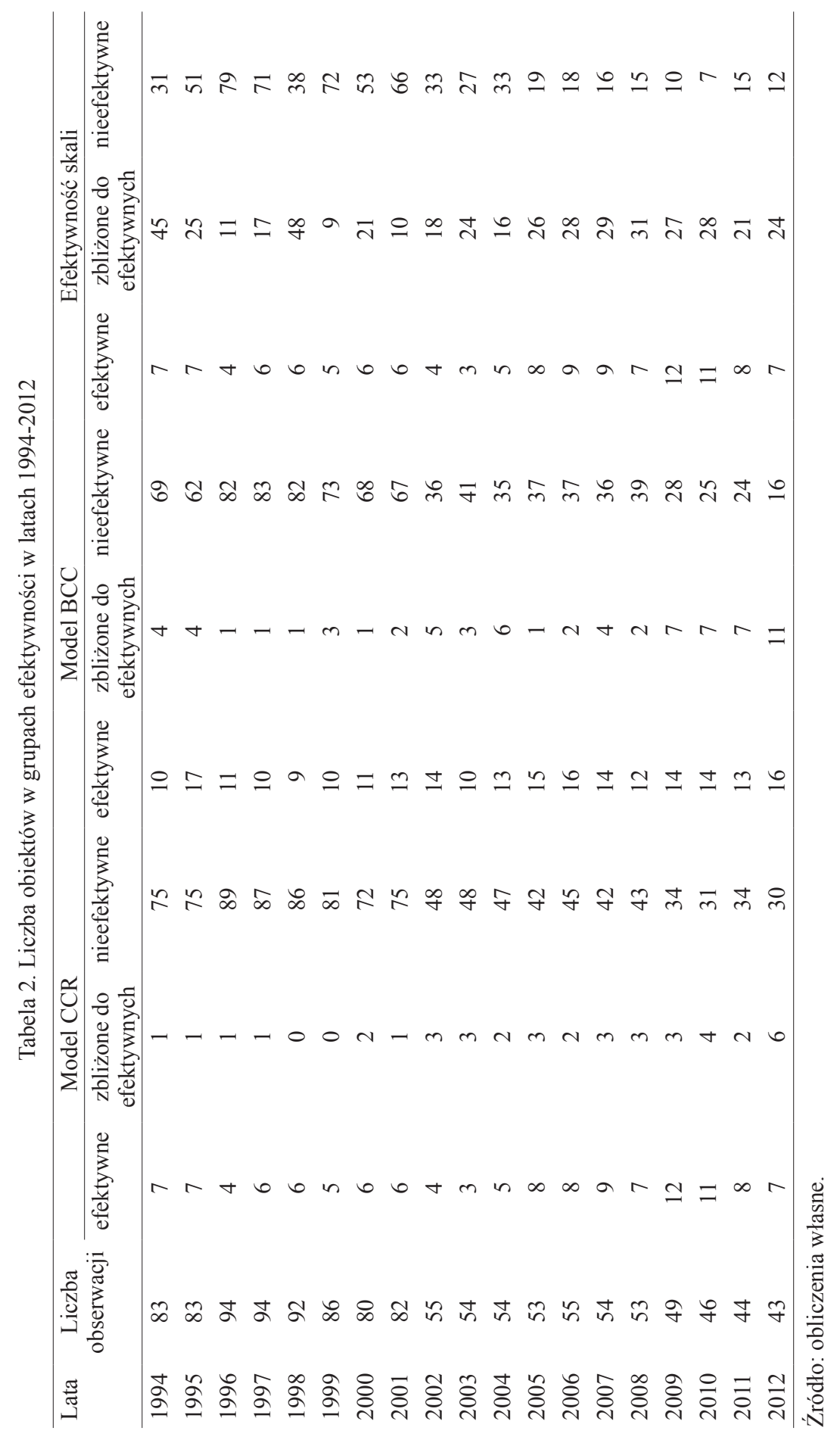




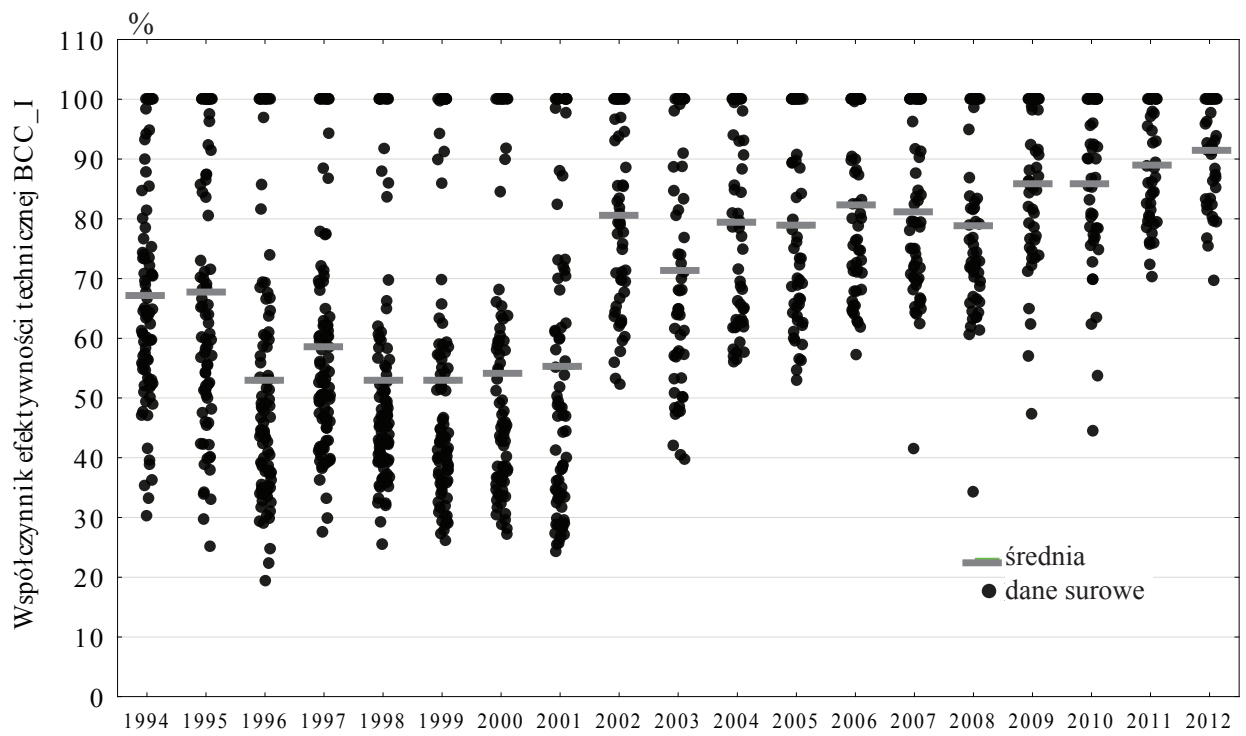

Rysunek 1. Współczynniki efektywności technicznej BCC badanych spółek w latach 1994-2012 obliczone dla modelu zorientowanego na minimalizację nakładów Źródło: opracowano na podstawie badań własnych.

Wyniki otrzymane metodą DEA zawierają rozwiązania modeli liniowych dla badanych spółek. Na ich podstawie określa się tzw. luki produkcyjne (nadmiar nakładów) w spółkach nieefektywnych. Luki produkcyjne w badanych latach obejmowały propozycje redukcji wszystkich nakładów przyjętych do modelu (wartości majątku trwałego (tys. zł), kosztów zużycia materiałów i energii (tys. zł), kosztów płac wraz z pochodnymi (tys. zł), powierzchnia użytków rolnych (ha)). W ostatnim roku badań (2012) proponowane redukcje dla modelu BBC VRS ukierunkowanego na minimalizację nakładów w spółkach nieefektywnych wahały się od 4,1 do 32,7\%, co stanowiło 112867 tys. zł. Luki produkcyjne dla kosztów zużycia materiałów i energii określono na kwotę 65450 tys. zł (3,8-36,9\%), dla kosztów płac wraz z pochodnymi 31361,6 tys. zł (3,8-30,4\%), dla powierzchni użytków rolnych na 13010 ha (3,8-32,2\%).

Propozycje zmniejszenia wartości majątku trwałego po części wynikają z faktu, że w momencie tworzenia badane spółki zostały wyposażone we wszystkie obiekty budowlane należące do ośrodków gospodarczych, w zasadzie bez możliwości ich wyłączenia w dalszych pracach organizacyjnych i bez względu na ich przydatność gospodarczą. Należy pamiętać, że w strukturze środków trwałych budynki i budowle mają znaczny udział. Analizy wymaga też uzbrojenie techniczne pracy np. ze względu na jego wykorzystanie.

Propozycje redukcji kosztów zużycia materiałów i energii wymagają szczegółowej analizy ekonomiczno-rolniczej i określenia na podstawie jej wyników, jaką część tych kosztów stanowią koszty związane z nakładami plonotwórczymi, czy nakłady te zostały zastosowane we właściwych terminach agrotechnicznych (w powiązaniu z przebiegiem pogody, zadaniami hodowlanymi). Wielkość luki produkcyjnej kosztów zatrudnienia wraz z pochodnymi stawia pytanie o racjonalność zatrudnienia w badanych spółkach. 
MIROSŁAW HELTA

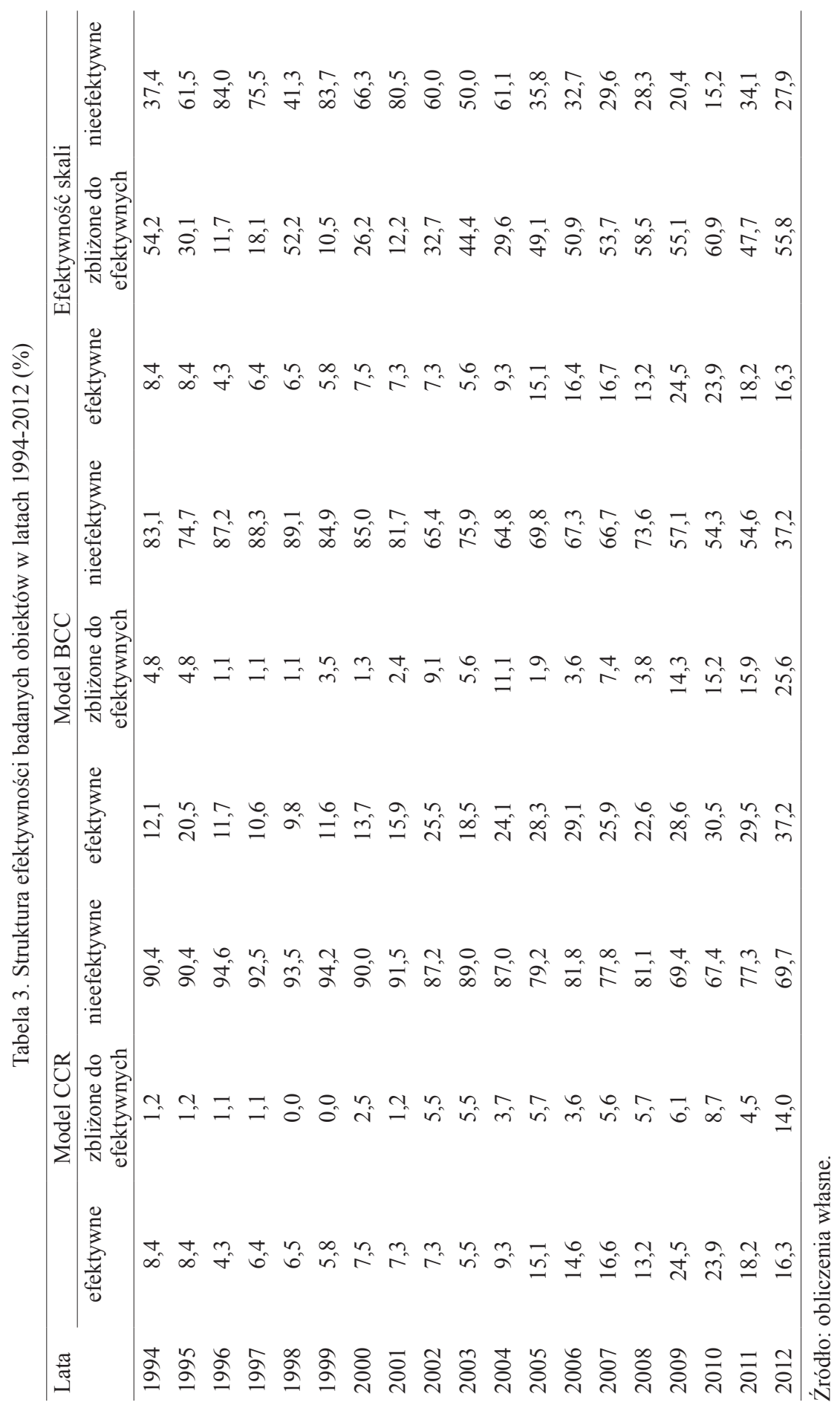


Konieczna jest ocena poziomu zatrudnienia w działach produkcyjnych w porównaniu do spółek utworzonych na majątku ANR przez podmioty prywatne oraz ocena zatrudnienia w działach hodowli roślin i zwierząt. Wykazywana luka produkcyjna w powierzchni użytków rolnych jest spowodowana przez tworzenie przez ANR rezerwy gruntów przeznaczonych na cele reprywatyzacji.

W strukturze efektywności technicznej (tab. 3.) badanych obiektów zachodziły zmiany. W grupie obiektów efektywnych i zbliżonych do efektywnych w modelu CCR w 1994 roku znajdowało się 9,6\%, a w 2012 roku 30,3\% obiektów. W modelu BCC udział obiektów efektywnych i zbliżonych do efektywnych wynosił odpowiednio 16,9 i 62,8\%, a w efektywności skali 62,4 i 72,1\%.

W tabeli 1. i na rysunkach 2.-4. przedstawiono wyniki badań. Efektywność techniczna CCR (rys. 2.) w zbiorowości ogólnej badanych obiektów (O CCR) w okresie 1994-2001 charakteryzowała się tendencją spadkową (z 57,7\% w 1994 r. do 33,2\% w 2001 r.). Od 2002 r. do 2012 r. przeciętne współczynniki efektywności technicznej CCR miały tendencję rosnącą (z 65,3 do 82,6\%). Oznacza to, że poszczególne nakłady ujęte w modelu w latach 1994-2001 można było zmniejszyć o 42,3-66,8\% bez zmiany efektów. W latach 2002-2012 zmiany w nakładach były mniejsze i wynosiły od 44,7 do $17,4 \%$.

Na rysunku 3. przedstawiono współczynniki efektywności technicznej BCC obliczone dla zbiorowości ogólnej badanych przedsiębiorstw i w podziale na grupy: hodowla roślin (HR), hodowla zwierząt (HZ) i stadniny koni (SK). Poszczególne analizowane grupy przedsiębiorstw charakteryzowały się różną efektywnością techniczną BCC. W wynikach obliczeń modelu BCC zaobserwowano podobne tendencje jak w modelu CCR. Od 1994 do 2000 roku notowano spadek współczynników efektywności technicznej BCC z 67,2\% w 1994 roku do 54,0\% w 2000 roku. Od 2001 roku następował wzrost wielkości współczynników efektywności technicznej BCC z 55,0 do 91,5\% w 2012 roku. W modelu BCC najwyższe współczynniki efektywności technicznej odnotowano w grupie spółek hodowli

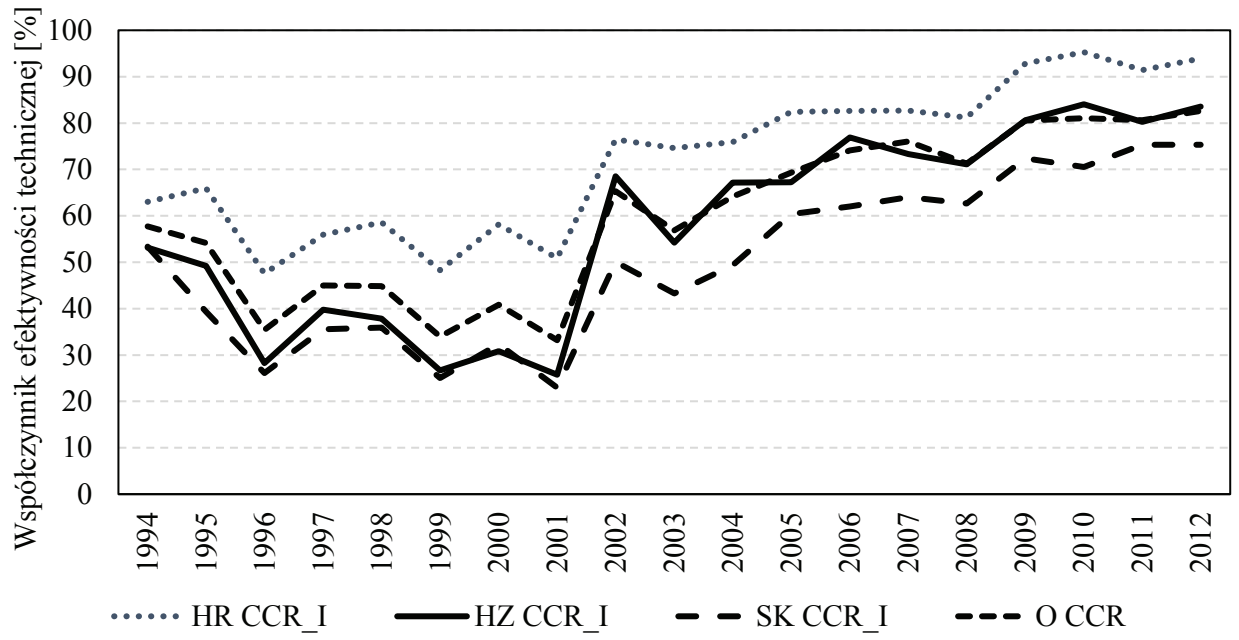

Rysunek 2. Przeciętne współczynniki efektywności technicznej CCR badanych spółek według grup w latach 1994-2012 obliczone dla modelu zorientowanego na minimalizację nakładów Źródło: opracowano na podstawie badań własnych. 


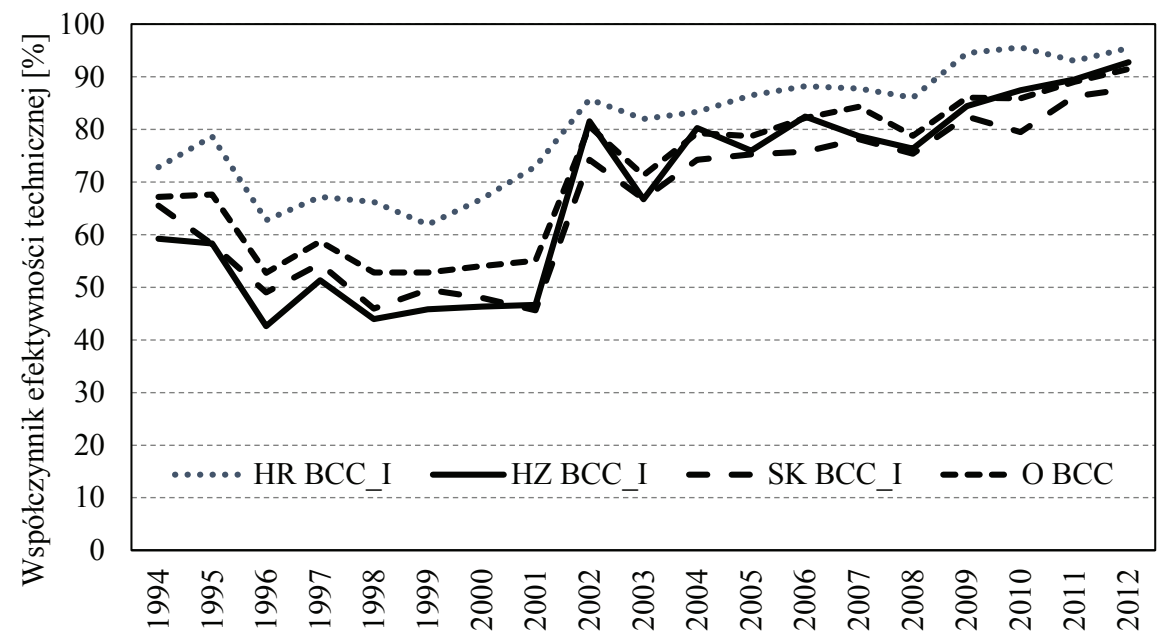

Rysunek 3. Przeciętne współczynniki efektywności technicznej BCC badanych spółek według grup w latach 1994-2012 obliczone dla modelu zorientowanego na minimalizację nakładów (inputs) Źródło: opracowano na podstawie badań własnych.

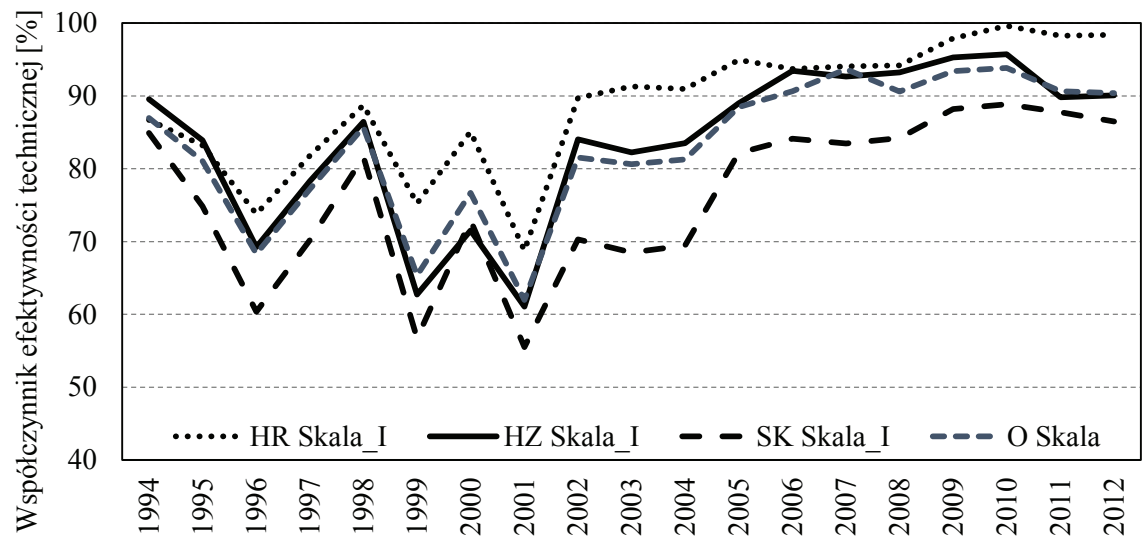

Rysunek 4. Przeciętne współczynniki efektywności skali badanych spółek według grup w latach 1994-2012 dla modelu zorientowanego na minimalizację nakładów Źródło: opracowano na podstawie badań własnych.

roślin (HR BCC_I). Uwagę zwraca fakt, że w tej grupie wzrost współczynników efektywności technicznej rozpoczął się od 1999 roku. W pozostałych analizowanych grupach wzrost ten rozpoczął się od 2001 roku. W grupie spółek hodowli zwierząt (HZ BCC_I) w latach 1994-2001 obserwowano najniższe współczynniki efektywności technicznej. Od 2002 roku ich wielkości pokrywały się z wielkościami przeciętnymi dla badanej zbiorowości ogólnej. Grupa stadniny koni (SK BCC_I) od 2001 r. charakteryzowała się najniższymi współczynnikami efektywności technicznej BCC.

Efektywność skali (rys. 4.) jest relacją wyników uzyskanych w modelu CCR do wyników modelu BCC. Współczynniki efektywności skali obliczone dla zbiorowości ogólnej i poszczególnych grup miały w latach 1994-2001 tendencje spadkowe. 
W latach 1996, 1999, 2001 wystąpiły we wszystkich badanych grupach duże spadki. W zbiorowości ogólnej (O Skala) odnotowano spadek z 87\% (1996 rok) do 62\% (2001 rok). Od 2002 roku następował wzrost współczynnika efektywności skali z 81,6 do 90,4\% w 2012 roku. Najwyższymi współczynnikami efektywności skali charakteryzowała się grupa spółek hodowli roślin(HR Skala_I). Efektywność skali w grupie spółek hodowli zwierząt (HZ Skala__ pokrywała się z efektywnością skali obliczoną dla całej zbiorowości, a grupa spółek stadnin koni (SK Skala_I) miała najniższe współczynniki efektywności skali spośród badanych grup.

\section{WNIOSKI}

Na podstawie wyników badań nad efektywnością techniczną spółek sformułowano następujące wnioski:

1. Współczynniki efektywności technicznej CCR, BCC i współczynniki efektywności skali w latach 1994-2012 charakteryzowały się tendencją rosnącą. W zbiorowości badanych obiektów współczynnik efektywności technicznej CCR w latach 1994-2012 wzrósł z 57,7 do 82,6\%. Współczynniki efektywności technicznej BCC w badanym okresie wahały się od 67,2 do 91,5\%, a współczynniki efektywności skali wynosiły odpowiednio 87,0 i $90,4 \%$.

2. W analizowanych grupach obiektów najwyższą efektywnością techniczną CCR, BCC oraz efektywnością skali charakteryzowały się obiekty zaliczane do grupy spółek hodowli roślin, następnie do grupy spółek hodowli zwierząt. Najniższe współczynniki efektywności technicznej CCR, BCC i efektywności skali odnotowano w grupie spółek stadnin koni.

3. Oceniając wyniki badań, należy pamiętać o następujących trzech faktach: że metoda DEA jest metodą analizy stosowaną do tzw. analiz pierwszego kontaktu, informujących o należytym wykorzystaniu nakładów i odpowiedniej wysokości efektów; po drugie, że metoda ta dostarcza wyników, które odnoszą się wyłącznie do badanej grupy, oraz że współczynniki efektywności technicznej zwiększają się wraz ze zmniejszaniem się liczebności badanej zbiorowości. W celu weryfikacji powyższych badań i ustalenia zmian w racjonalności gospodarowania w dalszych badaniach należy posłużyć się metodą SFA, indeksem Malmquista oraz wykonać typową analizę ekonomiczno-rolniczą badanych spółek.

\section{LITERATURA}

Banker Rajiv D., Abraham Charnes, William W. Cooper, 1984: Some Models for Estimating Technical and Scale Inefficiency in Data Envelopment Analysis, „Management Science”, 30, s. 1078-1092.

Baran Joanna, 2010: Efektywność skali produkcji w sektorze przetwórstwa mleka. Rozprawa doktorska. SGGW, Warszawa.

Battese George E., Tim J. Coelli, 1992: Frontier production functions, technical efficiency and panel data: With application to paddy farmers in India, ,Journal of Productivity Analysis”, 3, s. 153-169.

Charnes Abraham, William W. Cooper, Edwardo Rhodes, 1978: Measuring the efficiency of decision making units, „European Journal of Operational Research”, vol. 2, Issue 6, s. 429-444.

Coelli Tim, Rao D.D. Prasada, George Battese, 1998: An introduction to efficiency and productivity analysis, Kluwer Academic Publishers, Boston-Dordrecht-London.

Czasch Britta, Alfons Balmann, Martin Odening, 1999: Organisation und Effizienz landwirtschaftlicher Unternehmen während der Umstrukturierung des Agrarsektors. Eine empirische Analyse für Brandenburg, „Finanzwissenschaftliche Diskussionsbeiträge, Wirtschafts- und Sozialwissenschaftliche Fakultät", Universität Potsdam, Industrial and Social Policies in Countries in Transition, Potsdam, no. S-11, s. 9-19. 
Góral Justyna, 2015: Subsydia a efektywność techniczna wielkotowarowych gospodarstw rolnych, Rozprawa doktorska, IERiGŻ-PIB.

Guzik Bogusław, 2009: Podstawowe modele DEA w badaniu efektywności gospodarczej i społecznej. UE, Poznań.

Helta Mirosław, Artur Oprządek, 2012: Rola spótek Agencji Nieruchomości Rolnych w upowszechnianiu postępu biologicznego, „Wieś i Rolnictwo”, nr 3, s. 177-203.

Jarzębowski Sebastian, 2015: Efektywność gospodarowania przedsiębiorstw mlynarskich w Polsce $i$ w Niemczech. Rozprawa doktorska, SGGW, Warszawa.

Kulawik Jacek (red.), 2008: Analiza efektywności ekonomicznej i finansowej przedsiębiorstw rolnych powstałych na bazie majątku WRSP, IERiG-PIB, Warszawa.

Marzec Jerzy, Andrzej Pisulewski, 2013: Ekonometryczna analiza efektywności technicznej farm mlecznych $w$ Polsce na podstawie danych z lat 2004-2011, „Roczniki Kolegium Analiz Ekonomicznych SGH”, z. 30, s. 255-271.

Marzec Jerzy, Andrzej Pisulewski, Artur Prędki, 2015: Efektywność techniczna gospodarstw mlecznych w Polsce - analiza porównawcza za pomoca DEA i BSFA, „Metody Ilościowe w Badaniach Ekonomicznych", vol. XVI, nr 4, s. 7-23.

Rogowski Grzegorz, 1998: Metody analizy i oceny działalności banku na potrzeby zarzadzania strategicznego, Wydawnictwo Wyższej Szkoły Bankowej, Poznań.

Rusielik Robert, 2000: Pomiar efektywności gospodarowania spółek Agencji Własności Rolnej Skarbu Państwa w latach 1996-1998 z wykorzystaniem metody DEA, Rozprawa doktorska, SGGW.

Rusielik Robert, Michał Świttyk, 2012: Efektywność techniczna produkcji mleka w wybranych europejskich gospodarstwach w latach 2008-2010, „Roczniki Nauk Rolniczych. Seria G Ekonomika Rolnictwa", t. 99, z. 1, s. 88-99.

Szymańska Elżbieta, 2011: Efektywność gospodarstw wyspecjalizowanych w produkcji żywca wieprzowego w Polsce, Rozprawy Naukowe i Monografie SGGW, Warszawa.

Świttyk Michał, 2001: Badanie efektywności spótek dzierżawiących nieruchomości rolne w województwie gorzowskim za pomocą metody DEA (Data Envelopment Analysis), „,Folia Universitatis Agriculturae Stetinensis: Oeconomica", nr 216, 39, s. 227-242.

Świttyk Michał, 2011: Efektywność polskiego rolnictwa w latach 1998-2009, „Zagadnienia Ekonomiki Rolnej", nr 4, s. 59-75.

Thiele Holger, Claus M. Brodersen, 1997: Anwendung der nicht-parametrischen Data Envelopment Analysis auf die Effizienz Landwirtschaftlicher Unternehmen in der Transformation Ostdeutschland, „Agrarwirtschaft”, nr 46, s. 407-415.

Ziółkowska Justyna, 2008: Efektywność techniczna w gospodarstwach wielkotowarowych, „Studia i Monografie", nr 140, IERiGŻ-PIB, Warszawa.

\title{
Mirosław Helta
}

\section{THE TECHNICAL EFFICIENCY OF THE AGRICULTURAL PROPERTY AGENCY COMPANIES BETWEEN 1994 AND 2012}

\begin{abstract}
Summary
The aim of the study was to determine the effectiveness of strategic companies owned by the Agricultural Property Agency in the period 1994-2010 using the DEA method. Between 1994 and 2012 the technical efficiency factors of $C C R, B C C$ and coefficients of scale efficiency were characterized by a growing trend. In the universe of objects of the CCR, between 1994 and 2012 the technical coefficient of performance rose from 57.7 to $82.6 \%$. The technical efficiency factors of the BCC ranged from $67.2 \%$ to $91.5 \%$ during the period, and scale efficiency ratios were respectively $87.0 \%$ and $90.4 \%$. In the analysed groups of objects, the objects included in the plant breeding group (HR) and the animal breeding group (HZ) were characterized by the highest technical efficiency of CCR, $B C C$ and scale performance. The lowest coefficients of technical efficiency were observed in the horse stables (SK).

Adres do korespondencji: Mirosław Helta Agencja Nieruchomości Rolnych 00-189 Warszawa, ul. Inflancka 4 e-mail: miroslawhelta@wp.pl
\end{abstract}

